\title{
Modern İktisadın Öğretilmesinde Gazetelerin Rolü ve Gazetelerdeki İktisat Kitabı Tefrikaları (1860-1870 Dönemi)
}

\author{
Kenan Demir ${ }^{1}$
}

Öz

Klasik İktisat Düşüncesi 1776 senesinde Adam Smith'in eseriyle ortaya çıktıktan sonra Osmanlı Devleti'nde bu düşüncenin görüşleri 1830'lu yıllarda ülkede ikamet eden Blak Bey, David Urquhart ve Churchill tarafından dönemin gazetelerinde dillendirilmeye başlanmıştır. 1830'larda bu şahıslar tarafından bu düşüncenin girmesinden sonra ülkede Batılı anlamda ilk ekonomi kitapları yayımlanmaya başlamış, sırasıyla Serendi Arşizen, Sehak Abru, Charles Wells, Mehmet Şerif Efendi ve Mehmet Mithat'ın kitapları yayımlamıştır. Aynı zamanda Takvim-i Vekayi, Ceride-i Havadis, Tercüman-ı Ahval, Mecmua-i Fünun, Tasvir-i Efkar ve Terakki gazetelerinde ekonomi ilminin ilkeleri hakkında yazılar yayımlanmıştır. Bu çalışmada yayımlanan ilk kitaplar ve gazetelerde yayımlanan makalelere değinilmiştir. Sonra Mehmet Şerif Efendi'nin "il/m-i Emval-i Milliye" adlı ekonomi kitabı ile Mehmet Mithat'ın "Ekonomi Tercümesi: Fenni Idare" adlı ekonomi kitabının Tercüman-ı Ahval ve Terakki'de yayımlanmış bölümlerinin içeriği incelenmiştir.

Anahtar Kelimeler: Osmanlı Devleti, Gazeteler, Ekonomi İlmi, Eğitim

Atıf: Demir, K. (2018).Osmanlı'da Ekonomi-Politik IIminin Öğretilmesinde Gazetelerin Rolü ve Gazetelerdeki

Ekonomi Kitabı Tefrikaları. Akdeniz Üniversitesi Iletișim Fakültesi Dergisi, (AKIL) Aralık (30) s. 260-280

1 Dr. Öğretim Üyesi, İstanbul Medipol Üniversitesi, İşletme ve Yönetim Bilimleri Fakültesi, kdemir@medipol. edu.tr 


\title{
The Role of Newspapers in Teaching Modern Economics and the Book of Economics in the Newspapers (1860-1870 Period)
}

\begin{abstract}
After the idea of Classical Economic Thought appeared in 1776 with Adam Smith's work, the views of this thought in the Ottoman Empire began to be expressed in the newspapers of the period by Blak Bey, David Urquhart and Churchill who lived in the country in the 1830s. After the introduction of this idea in the 1830s, the first economics books in the country like that of Serendi Arshizen, Sehak Abru, Charles Wells, Serif Efendi and Mehmet Mithat began to be published in the country. At the same time articles on the principles of Economics were published in newspapers like Takvim-i Vekayi, Ceride-i Havadis, Tercüman-ı Ahval, Mecmua-i Fünun, Tasvir-i Efkar and Terakki. In this study, the first books and the articles published in the newspapers were analyzed. Then, the contents of Mehmet Şerif Efendi's book titled "IIIm-i Emval-i Milliye" and Mehmet Mithat's Ekonomi Tercümesi: Fenni Idare, which was publish part by part in Tercüman-ı Ahval and Terakki, were analyzed.
\end{abstract}

Keywords: Ottoman Empire, Newspapers, Science of Economics, Education 


\section{Giriș}

1776 senesinde Adam Smith'in Milletlerin Zenginliği kitabıyla ortaya çıkan klasik iktisat düşüncesi daha sonra Malthus, David Ricardo, J.B. Say ve J. S Mill ile zenginleşip sistemleştikten sonra dünyaya yayılmaya başlamıştır. Klasik İktisat düşüncesinin Osmanlı Devleti'ne girişi 1820'lerin sonlarından itibaren görülmeye başlamıştır. Osmanlı Devleti'ne klasik iktisat düşüncesinin girişi başta İngiliz vatandaşları olmak üzere ülkede bulunan yabancı kişiler tarafından dillendirilmiş ve aktarılmıştır. 1820’lerde yeni pazarlar arayışı içerisinde olan İngilizler, Yakın Doğu'ya gözlerini dikmiş ve Levant ticaretinde etkili olmak için çalışmaya başlamışlardır. Bu doğrultuda Osmanlı Devleti'yle ticari faaliyetlerini artırmak isteyen İngiliz bürokratları Osmanlı Devleti'nin iktisadi yapısı hakkında bilgi almak ve Osmanlı'yla bir ticaret anlaşması imzalatmak amacıyla başta David Urquhart olmak üzere gizli görevli elçiler göndermiş ve İngiliz konsolosluğu bu alanda önemli çalışmalarda bulunmuştur. David Urquhart’tan başka Fransız Blak Bey de iktisat düşüncesinin yayılmasında önemli hizmetlerde bulunmuştur. Blak Bey önce İzmir'de çıkardığı gazetelerle; sonra da devletin resmi yayın organı olan Le Moniteur Ottoman'daki görüşleriyle klasik iktisat düşüncesinin yayılımında önemli rol oynamıştır. 1840 senesinde ülkede yayımlanan Ceride-i Havadis'in sahibi İngiliz tüccar Churchill de gazete sütunlarındaki görüşleriyle klasik iktisadın yayılımında rol oynayan önemli diğer bir şahıstır.

Klasik iktisat düşüncesinin ülkede yayılımını hızlandıran en önemli etken 1838'te imzalanan Balta Limanı Ticaret anlaşmasıdır. Serbest iktisat düşüncesi ilkeleri doğrultusunda imzalanan ticaret anlaşması sonrası modern iktisat fikirleri ülkede hızla yayılmıştır. 1820'lerden sonra ülkede görülmeye başlayan klasik iktisat düşüncesinin ne olduğuna ait ilk iktisat yayımları 1850'lilerde görülmüş, yayımlanan iktisat kitapları dönemin önemli haberleşme aracı olan gazeteler vasıtasıyla Osmanlı halkına aktarılmıştır. Osmanlı'da eğitim kurumların gelişmemiş olması nedeniyle ülkede modern iktisadın öğretilmesinde gazeteler önemli rol oynamışlardır. Bu çalışmada ekonomi ilmi hakkında dönemin yayın organlarındaki bilgilendirici ve öğretici yazıları tespit edilmiş ve bu yazıların içeriği incelenmiştir. Ayrıca dönemin ilk iktisat kitaplarının gazetelerdeki tefrikaları tespit edilmiş sonra da ekonomi ilminin öğretilmesi ve halkın eğitilmesinde gazetelerin oynadığı rol dile getirilmiştir.

Gazetelerde bir iktisadi düşünceyi anlatan ve benimseyen yazıların görülmesiyle birlikte iki iktisadi kitabın tefrikası da yer almıştır. Bu tefrikalardan ilki Tercüman-ı Ahval gazetesi'nde Şerif Efendi tarafından 1861 senesinde yayımlanmıştır. Şerif Efendi, kitabı önce gazetede tefrika ettikten sonra 1863 senesinde neşretmiştir. İkinci ise Terakki gazetesi'nde 1869 yılında Mehmet Mithat tarafından yazılan kitabın tefrikasıdır. Bu iki tefrika yazısı daha çok öğretici bir üslupla yazılmıştır. Bu tefrikalarla halkın modern iktisadi konulara ait bilgisi artırılmaya çalışılmıştır. Bu iki tefrikada anlatım şeklinin iki kişinin karşılıklı konuşma şeklinde olması ve birinin sorular sorarak bir hoca-öğrenci havasının verilmesi daha çok iktisadi kavramların halka öğretilmeye çalışılmasının kanıtıdır. Bu tefrikalardan Mehmet Mithat'ın tefrikası halk dilinde olup günlük olaylardan örnekler verilerek iktisadi konular anlatılmıştır. Bu iki tefrikanın gazetelerde yer alması, basının ekonomi ilmini halka öğretmeye çalıştığının göstergesidir. 
Çalışmanın ana amacı ülkede kamuoyunu oluşturan özel gazetelerin yayımladığı 1860 senesinden itibaren gazetelerin halkın modern iktisat öğretilmesinde oynadığı rolü göstermektir. 1860 senesinde yayımlanan Tercüman-ı Ahval, Tasvir-i Efkar, Mecmua-ı Fünun, Mirat, Takvim-i Ticaret, Muhbir, Hürriyet ve Terakki gibi gazetelerin yayım politikasıyla ülkede ilk defa devlet dışı bir özel kamuoyu oluşmuş ve halk aydınlatılmaya çalışıımıştır. Osmanlı gazetelerin halkı aydınlatmanın yanında onların bilgi seviyesini artıracak bir yayım politikası da gütmüş ve Osmanlı gazeteleri ülkede gelişmeyen laik eğitim kurumların görevlerini icra ederek bir okul hizmeti vazifesini icra etmişlerdir. 1860 dönemi Osmanlı gazetelerin değindiği konulardan biri de iktisat ilmi olmuştır. Gazetelerde birçok iktisat yazısı yer almıştır. Bu dönemde gazetelerde ilk defa iki iktisat kitabın tercümesi yapılmıştır. Tercüman-ı Ahval gazetesinde 1861 senesinde Mehmet Şerif Efendi’nin tefrika edildiği ‘'Im-i Emval-i Milliye” ülkede tefrika edilen ilk iktisat kitabıdır. ${ }^{2} 1869$ senesinde Terakkide yayımalanan Mehmet Mithat'ın “Ekonomi Tercümesi: Fenni Idare'de ikinci iktisat kitabıdır. Bu iki kitabın seçimin nedeni ülkede ilk iktisat kitap teftikaları olmasıdır.

\section{Osmanlı'daki Eğitim Sistemi ve Modern Eğitim Kurumları}

Osmanlı'da eğitim Tanzimat dönemine kadar sadece medreselerde verilmiş, ülkenin sivil ve askeri personeli medreselerden karşılanmıştır (Kazıcı, 2004: 85-86). Klasik dönemde eğitim ilköğretim düzeyinde mahalle mektepleri ve yüksek düzeyda ise medrese olarak iki aşamayla verilmekteydi. Bu mekteplerde genellikle dini eğitim verilmiştir. Mahalle mektepleri varklıklı mahalle sakinleri tarafından kurulmuş ve giderleri dini vakıflar tarafından sağlanmıştır. Bu yöntem sonucu halkı eğitme vazifesi cemaat içinde dini kurumlar tarafından icra edilmiştir (Somel, 2010: 38-39). Yüksek eğitim kurumları olan medreseler ise klasik dönemde ülkenin askeri ve mülki personelini yetiştirecek düzeyde akli ve dini bilimler doğrultusunda eğitim vermişlerdir. Medreselerin de finansmanı vakıf sistemiyle karşılanmış, bu da medreselerin zamanla akli ilimlerden ziyade sadece dini eğitimin yapıldığı bir eğitim sürecine götürmüştür (Ürekli, 2002: 385-387). Avrupa'da eğitim yöntemleri ve ders programları değişirken, Osmanlı medreselerinde herhangi bir değişim yaşanmamış ve medreseliler eğitimde görülen ufak tefak yenilik hareketlerine de engel olmuşlardır (Kodaman, 1991: 2).

Osmanlı Devleti'nde eğitimin düzenlenmesi reform hareketlerinin devam ettirilmesi ve kalıcılaşması için önemli bir adım olarak görülmüştür ve bu doğrultuda eğitim modern bilgiler ışığı altında laikleştirilmeye çalışılmıştır (Kanat, 2018: 486). Dini eğitimin hakim olduğu bir eğitim sisteminden 19. yüzyılın başlarında ordu ve mülki idarelerin modernleşmesiyle laik eğitim sistemi doğrultusunda ilk eğitim kurumları açılmaya başlanmıştır (Ortaylı, 2000: 186). Modern eğitim kurumlarında ilk örnekler askeri okullarda olmuş, bu doğrultuda eskiden açılan Mühendishane okulu geliştirilmiş, Tıbbiye yeniden kurulmuş ve Harbiye okulu açılmıştır. Modern eğitim kurumları Batı tarzda eğitim vermeye başlarken ilk öğretimde halen dini eğitim baskınlığını korumuş bu da modern laik eğitimin yaygınlaşmasını engellemiştir (Berkes, 2003: 184).

2 Osmanlı ilk iktisat kitabı olan ilmi Risale-i Tedbir-i Umran-ı Mülki' kitabı Takvim-i Vekayi'de tefrika edilmemiştir. Sadece Malthus doğrultusunda nüfus konusu gazetenin 54 ve 55 sayılarında yayımlanmıştır. 
Osmanlı'da 1859 senesinde kız ve erkek öğrenciler için sanayi mektepleri kurulmasının planlanmasına karşın gerekli altyapıların olmaması nedeniyle herhangi bir adım atılamamıştır (Ortaylı, 2000: 188). Ülkenin teknik ve uzman kadrolarını yetiştirmek amacıyla meslek okulları açılmıştır. Bu doğrultuda 1847 senesinde Ziraat Mektebi, 1859 senesinde Baytar Mektebi 1860 senesinde Orman Mektebi eğitim hayatına başlamıştır. Bu meslek okulları ilköğretimden ziyade yüksek öğretim eğitimi vermesiyle ülkede mesleki eğitim yaygınlaşamamıştır (Ortaylı, 2000: 188). Cevdet Paşa'nın dediği gibi eğitimde modernleşme ilk öğretimden değil "orta yerden" başlamış bu da modern eğitimin yaygınlaşmasını engellemiştir (Gündüz, 2015: 67). 1862 senesinde mahalle mekteplerin ıslah edilmesine çalışılmasına karşın bir ilerleme sağlanamamış ve mahalle mekteplerinde modern eğitimin verilmesi ancak 1880'lerde gerçekleşmiştir (Gündüz, 2015: 71,87).

Osmanlı bürokratları ülkenin iktisadi politikalarını kendinden önceki devletin yönetim tecrübelerinden istifade ederek yürütmüştür. Bürokratların uyguladıkları iktisat politikaları akademik iktisat teorilerine dayanmamıştır (Sayar, 2001: 123). Osmanlı iktisat politikaları modern iktisat biliminin öne çıkardığı birey yerine devleti ön planda tutan "il/m-i Tedbir-i Devlef' doğrultusunda yürütülmüştür. Devlet iktisada hakim olmuş, tüm iktisadi mekanizmaları bireylere bırakmamış, kendisi yürütmüştür (Sayar, 2001: 123). Osmanlı bürokratları iktisat politikalarına iktisadi verim mefhum açıdan ancak 1830'larda İngilizlerin tasviyesiyle yaklaşmaya başlamış, bu da ülkenin modern iktisatla tanışmasını sağlamıştır (Sayar, 2001: 116). Başlangıçta modern iktisada mesafeli olan Osmanlı insanı 1850'lerden sonra iktisada rağbet etmiştir (Sayar, 2006: 256). Osmanlı'da modern iktisat eğitimi 1840'lara kadar görülmemiştir. Klasik dönemde iktisat eğitimi İslam kültür etkisiyle oluşan İlm-i Tedbr-i Menzil kavramı altında verilmiştir (Orman, 2001: 303-304). İlmi- Tedbir-i Menzil İslam ilimler tasnifinde ameli felsefe kısmında yer almış ve ev ekonomisini konu edinmiştir. İlm-i Tedbir-i Menzil kavramı Türkçe'ye ev yönetimi olarak çevirilebilir (Beşer, 2014: 8). İlm-i Tedbr-i Menzil ile Yunan felsefesinin Oikonomia arasında hem muhteva hem isim arasında doğrudan bir ilişki olmuş ve İlm-i Tedbir-i Menzil Aristo felsefesinden etkilenmiştir (Orman, 1992: 251). İmi Tedbir-i Menzil, ev ve aile toplumunu temel bir sosyal ve ekonomik birimi olarak görmüş ve iktisadı ev ekonomisi doğrultusunda evin gelir-gider yönetimini dikkate almıştır (Orman, 1992: 280).

Modern iktisat ilk defa Mekteb-i Tıbbiye'de Serendi Arşizen tarafından verilmiştir. Bu eğitim hakkında fazla bilgiye sahip olmamıza rağmen dersde Rossi'den çevirdiği "Cours d'Economie Politik" adlı kitabı okutmaktaydı. Aslında bir iç hastalıkları doktoru olan ve Tıbbiye'de hekimlik dersi veren Arşizen iktisat dersi de vermiştir (Sayar, 2001: 128). Osmanlı'da ilk defa sistemi bir şekilde iktisat dersi 1859 senesinde açılan Mülkiye Mektebi'nde verilmiştir (Fındıkoğlu, 1946: 32). İktisat dersi mektebin ikinci senesinde "Ekonomi Politik yani İstihsal-i Servet ve Yesari-i Mülk ve Tebaa" adı altında Tercüme Odası hulefasından Emin Efendi tarafından verilmiştir (Ergin, 1977: 599). Emin Efendi'nin istifa etmesinden sonra iktisat dersini Mekteb-i Mülkiye Coğrafya Hocası Cevdet Efendi vermiştir (Çankaya, 1969: 77). Sonra mektepte iktisat derslerini Mehmet Şerif Efendi vermiş ve ders notlarını "il/m-i Emval-i Milliye” adıyla neşretmiştir (Keçetep, 
2016: 825). Bu çalışmanın konusu olan gazetelerin ekonomi ilmini öğretiminde rolünün fazla olmasının nedeni yukarıda ifade edildiği gibi ülkede modern eğitim kurumların sadece yükseköğretimde sınırlı bir şekilde kurulmasıdır. Eğitimi halen geleneksel dini eğitim doğrultusunda veren medreselerin kaldırılmamasıdır. Bu dönemde sadece Mekteb-i Tıbbiye ve Mekteb-i Mülkiye okullarında iktisat dersi verilmiştir. Bu da gazetelerin iktisadın öğretilmesinde bir eğitim kurumu olarak önemli olmasını sağlamıştır.

\section{Gazetelerdeki Ekonomi Illmi Hakkındaki Yazılar ve Yayımlan IIk Kitaplar}

Osmanlı Devleti'nde yeniliğin yaygınlaşmasında önemli katkı sağlayacak kurumlardan biri de yine 19. yüzyılda görülen gazetelerdir (Tanpınar, 2001: 146). Gazeteler, toplumdaki gelişmeleri aktararak, toplumsal olayları ve yönetim politikalarına karşı kamuoyunun tepkisini ölçmede önemli bir güç kazanmış ve kamuyounu yönlendirmiştir (Gündüz, 2018: 17). 1860’lı senelerden itibaren gazeteler olayları nakletmekten ziyade okurlara faydalı bilgiler vererek halka eğiten bir kurum haline gelmiştir. Gazeteler gerçek anlamda bir kürsü rolünü oynamış ve fikirler gazete sayesinde yapıcı bir unsur olarak topluma yayılmıştır. Gazeteler aracılığıyla vatan, millet, hürriyet, hak, adalet ve insanlık gibi mefhumlar doğrultusunda yeni bir insan tipi teşekkül etmiştir (Tanpınar, 2001:249). Gazelerin etkisiyle özgürlük ve meşrutiyet gibi kavramlar Osmanlı toplumunda yayılmış ve ülkede kendini özgürce ifade eden bireyler ortaya çıkmıştır (Kaya, 2018: 38). Ülkede gazeteler düşüncenin topluma yayılmasında önemli rol oynamış, kalabalıklar gazeteler etrafında toplanmış, halka okumayı öğretmiş ve bir mektep vazifesi görerek halkı eğitmiştir (Tanpınar, 2001: 250). Gazetelerin yaygınlaşmasıyla çeşitli bilgi kaynaklarına halkın doğrudan ulaşabilme imkanı doğmuş ve halkın bilgiye ulaşabilme süreci kolaylaşmıştır (Karpat, 2013: 187). Gazeteler bu dönemde halkta iyi yada kötü ahlakın ve fen ve sanat bilgisinin oluşmasında önemli görevler görmüştür (Koloğlu, 2010b: 158). Osmanlı'da gazeteler bir toplumun haber alma ve eğlenme fonksiyonunda yanında aynı zamanda toplumun kültürel değişimini sağlayarak demokratikleşmesini de sağlamıştır (Kadıŏlu, 2018: 100). Ülkenin modernleşmesinde önemli katkılar sağlayan gazeteler müslim-gayrimüslim eşitliğinin ve yerel meclislerle seçme ve seçilme alışkanlığının sağlanmasında önemli katkılar sağlamıştır (Doğaner, 2012:115).

Avrupa'da kitabın halkın bilgi seviyesinin artırılması ve eğitmede oynadığı rolü Osmanlı'da gazeteler üstlenmiştir. Bunun nedeni de kitabın ileri düzeyde uzmanlaşmış bir kitleye hitap etmesiydi. Ülkede okur yazar oranının düşük olması nedeniyle ülkede gazete kültürü oluşmuş, gazeteyle geniş bir kesim gündelik ve bilgilendirici bilgilere sahip olmuştur (Koloğlu, 2006: 24). Osmanlı'da okuryazarlık oranları 1860'lı senelerinde \%5 civarlarında idi. Bu da bilgiyi ulaşmayı zorlaştırmaktaydı. Okuryazarlık yeteneğini elde eden kişinin ilk başvuru kaynağı kitaptan ziyade gazetelerdi. Bu nedenle kitap yazarları da kitaplarını önce gazetelerde tefrika etmiş, sonra kitap halinde piyasa sürmüşlerdir (Koloğlu, 2010b: 157-158). Ayrıca ülkede modern okul sayısının fazla olmaması ve mevcut olan okullarda ders programlarının çoğunun dini ağırlıklı olması nedeniyle modern bilgiye ulaşmada gazetelerin önemini artırmış ve 
Tanzimat toplumu gazeteler aracılığıyla modern bilgilere ulaşmıştır (Orman, 2018: 242-243). Osmanlı'da gazeteler sadece olaylara ait bilgi ve haber aktarmaktan ziyade halkın kültürve eğitim seviyesini artıracak bilgi veren bir fikir gazeteciliği formatında yayımlarını sürdürmüştür (İnuğur, 1999: 192-193). Dönemin aydınları, gazetelerin toplumu etkileme gücünün farkında olduklarınından düşünce ve fikirlerini öncelikle gazeteler aracılığıyla vermiştir. Gazetelerin eğitici ve öğretici bir fonksiyonda olması gündelik hayattaki etkisini artırmasına neden olmuştur (Bulut, 2018: 72-73). Gazetelerin eğitim rolü üstlendiği sektörlerden biri de iktisat olmuş, gazetelerde ekonomi ilminin tarifi yapılmış, yararları anlatılmış, bankacılık, sanayi, ticaret ve ziraat gibi iktisadi sektörlerde halkın bilgi seviyesini artırıcı bilgiler verilmiştir. Ülkenin mali sorunların hakkında halk bilgilendirilmiş, fakirlerin durumu anlatılarak toplumsal sorunlarda halkın bilinçlendirilmesi artırılmıştır (Koloğlu, 2010a: 60-67).

Osmanlı'da ilk iktisat kitabı "Risale-i Tedbir-i Umran-ı Mülki” adlı bir yazmadır. 86 sayfa olan yazmanın kim tarafından yazıldığı bilinmemektedir. Kitap ekonomi politikten yapılmış bir çeviri olma intimali olup başvurduğu kaynaklar hakkında bir bilgi bulunmamaktadır. Risale yazarının kitapta Malthus'tan söz ederken yakında Takvim-i Vekayide Malthus hakkında tanıtıcı bir yazının neşredileceğini belirtmesi ve makalenin Takvim-i Vekayi'nin 54-55. sayılarında yayımlanması nedeniyle kitabın 1830'ların ilk yıllarında yazıldığı anlaşılmaktadır (Ortaylı, 1983: 39-40). Kitap giriş, beş bölüm ve sonuç kısımlarından oluşmaktadır. Giriş bölümünde teori çerçeve, birinci bölümde iktisat ilminin temel kavramları, ikinci bölümde üretim ve üretim faaliyetleri, üçüncü bölümde üretim fonksiyonları, dördüncü bölümde fiyat ve değer, beşinci bölümde ise nüfus sorunu anlatılmıştır (Ortaylı, 1983: 41-42). Yazar, eserin yazılma amacını merkezi hükümetin harcamaların artması nedeniyle iktisadi sistemin değiştiğini ve yeni bir iktisatdi anlayış ve bilginin gerekli olduğunu belirtmiş ve bu ilmi halka öğretmek amacıyla yazdığını açıklamıştır. Eserde devletin yerli tüccarları koruması ve ticaretin gelişmesi için gerekli tedbirleri alması gerektiği ifade edilmiştir (Ortaylı, 1983: 40). Yazar, Avrupa'daki ekonomi değişiminin askeri alandaki yeniliklerin sonucu olduğu ve Osmanlı'nın bu değişime ayak uydurması gerektiğini vurgulamıştır. Ayrıca ülkede modern ekonomi ilmi öğrenildikten sonra Avrupa devletleriinin iki yüz senede gösterdiği iktisadi kalkınmayı Osmanlı Devleti'nin yirmi senede gerçekleştireceğini belirtmiştir (Koloğlu, 2010a: 132). Yazar, merkantilizm, fizyokrat, tabii denge kuramcıları, Malthus, Say ve Ricardo'ya kadar birçok ekonomi sistemlerinden etkilenerek eserini oluşturmuştur (Ortaylı, 1983: 43). Yazar, eserinde Osmanlı'nın modern iktisada intibakını sağlamak için Avrupa'da neşredilen iktisat kitaplarının Türkçe'ye tercüme edilmesini, sanayi ve ticareti geliştirmek için ticaret meclislerinin kurulmasını önermiştir (Aydar, 2016: 34-35).

Ülkede yayımlanan ilk gazete olan Takvim-i Vekayi Osmanlı'da ilk iktisat kitabı olan “Tedbir-i Umran-ı Mülki” adlı eserin bazı bölümlerini 54 ve 55. sayılarında yayımlamıştır. Yayımlanan bölümlerde nüfus artışının önemine Malthus ve Estrada adlı iktisatçıların görüşlerine atıf yaparak değinmiştir (Koloğlu, 2010a: 132). Ülkede yayımlanan ikinci gazete olan Ceride-i Havadis, okuyucularının "ilm-i Tedbir-i Menzip" (Ekonomi İlmi) konusunda uyanık olmasını ve bu ilmi öğrenmelerini istemiştir. 1852 senesinde 
ekonomi ilmine değinen ilk yazıyı yayımlanmıştır (Berkes, 1975: 331-332). Yazıda dini bilgilerden sonra öğrenilmesi gereken ilmin hikmet-i ameliye denen ilimler olduğu belirtilmiş ve bu ilimler sonucu insanoğlunun maaşını kazandığını ifade etmiştir. Ayrıca gazete matbaasında halkın anlayacağı bir seviyede Tedbr-i Menzil kitabı basıp 20 kuruş fiyatla okurlarına satmıştır (Fındıkoğlu, 1946: 20-21). Bu kitabın yazarın bilinmemekte ve kitap hakkında herhangi bir bilgi bulunmamasına karşın Berkes bu kitabı Sehak Abru tarafından yazılma intimalinin olduğunu söylemektedir (Berkes, 1975: 332).

Ülkede ikinci ekonomi kitabını yazan Serendi Arşizen Mekteb-i Tıbbıye-i Şahane'de Fransızca iktisat dersleri vermekteydi (Sayar 2003a: 155-156). Arşizen, 1809 senesinde Silivri'de doğmuş, eğitim için İstanbul'a gelmiş ve burada Rum Mektebi'nde eğitimini tamamladıktan sonra Filibe Rum Okulu'nda öğretmenlik yapmıştır. Sonraları dönemin etkili bürokratı Mustafa Reşit Paşa'nın himayesinde Paris'e tıp eğitimine gönderilmiş, sekiz sene tıp eğitimi aldıktan sonra Mekteb-i Tıbbiye de hocalığa başlamıştır. (Sayar, 2003b: 116-117). Arşizen'in, Mekteb-i Tıbbıye'deki hocalığı 1838-1849 seneleleri arasında sürmüştür (Sayar, 2006: 263). Arşizen İtalyan iktisatçı Rossi'nin eserini Fransızca olarak tekrardan yazmış, eseri Aleko Suço Türkçe'ye "Tasarrufat-ı Mülkiye" adıyla tercüme etmiştir. (Çakmak, 2011: 113-11). Eser, Arşizen tarafından dönemin padişahı Sultan Abdülmecid'e takdim edilmiştir (Sayar, 2001: 23). Tasarrufat-ı Mülkiye kitabı bazı tarihçiler tarafından İtalyan iktisatçı Rossi'nin çevirisi olarak ifade edilmesine karşın eser, klasik iktisadi bilgileri ve Osmanlı için ekononmi politika önerilerini içeren özgün bir çalışmadır (Genç-Özgür, 2011: XVIII-XIX). Üç bölüm, mukaddime ve hatimeden oluşan kitap 128 sayfadır. Giriş kısmında ekonomi ilminin gerekliliği, Osmanlı'da sanayileşme tartışması, Avrupa'da işçi sınıfı ve işçi ücretlerin ortaya çıkışını incelemiştir (Sayar, 2003b: 123). Eserin birinci bölümünde "kuvvet-i maliyenin teşkili ve istihsali", ikinci bölümünde "tevzi ve mukasseme-i emvalin ahvall" ve üçüncü bölümde ise "esbab-ı maliyenin ahvaline" değinmiştir (Sayar, 2006: 264). Arşizen, Osmanlı için sanayileşmeyi önermiş, bir ülkenin gücünün coğrafi genişliğinden ziyade ticaret, tarım ve sanayi sektörlerinin gelişmişliğiyle ölçüleceğini vurgulamıştır. Ziraat ve sanayinin gelişmesinin ticarete bağlı olduğunu ve bir ülkede ticaretin gelişmesiyle bu sektörlerden daha fazla istifade edileceğini belirtmiştir. Arşizen, ticaretin herhangi bir kısıtlamaya maruz kalmadan serbest yapılmasını savunmuştur (Genç-Özgür, 2011: $\mathrm{XX})$.

Sehak Abru, ülkede yayımlanan üçüncü ekonomi kitabını çıkartmıştır. Abru, Say'ın "Catehisme d'Economie Politique" adlı eserini 1852 senesinde "Ilm-i Tedbir-i Menzil" adıyla tercüme etmiştir (Sayar, 2003a: 156). Abru, eseri tercüme ederken ekonomi politik karşılığını İlm-i Tedbir-i Menzil olarak çevirmesi ülkede bu tabirin yaygın bir şekilde kullanımının sonucudur (Orman, 2001: 358). Abru, 1823 senesinde İzmir'de doğmuş, eğitimini İzmir'deki Fransız ve Ermeni okullarından almıştır (Kılıç, 2012: 103). 1849 senesinde İstanbul'a gelerek Babıali Tercüme Odası'nda işe başlamış (Balcı, 2009: 107), sonra Hariciye Nezareti'nin çeşitli dairelerinde görev almış, uzun yıllar Ali ve Fuat Paşaların mütercimi olarak çalışmıştır. Abru'nun iktisat kitabı dışında birçok kitap çevirisi bulunmaktadır. Abru, aynı zamanda Encümen-i Danişin harici üyeliği de yapmıştır (Sayar, 2004: 263-264). Takvim-i Vekayi Fransızca tercümanğını da 1851- 
1856 senesi aralıklarında sürdürmüştür (Balcı, 2009: 108-109). Abru, Say'ın suallicevaplı otuz bölümden oluşan eserin formatını değiştirerek eseri nesir yöntemiyle yeniden yazmıştır. Bu nedenle kitap telif-tercüme olarak anlandırılmaktadır (Sayar, 2006: 266). Eser dönemin padişahı Abdülmecid'e takdim edilmiştir. Bu takdim edilme, yönetimin modern iktisat ilmini teşvik ettiğini göstermektedir. (Sayar, 2006: 255). Kitap uzun süre Türk iktisat düşüncesinin temelini teşkil etmiştir (Mardin, 2002: 75). Ancak eser, dar bir bürokrat kesiminden öte halk kesimlerine ulaşamamıştır (Sayar, 2001: 128). Eserde, bürokratların ve kamu harcamalarının azaltılması, tarafsız vergi düşüncesi ve politikaları, borçlanmanın sakıncaları gibi konular klasik iktisat düşüncesi doğrultusunda verilmiştir (Şener, 1994: 218-219). Abru, ayrıca 1851 senesinde gazete çıkarmak için devlete müracaat etmesine karşın teklifi kabul edilmemiştir (Ortaylı, 2011: 394).

1860 senesinde Charless Wells tarafından Londra'da Türkçe yazılan 'İlm-i Tedbir-i Mülk" yayımlanan diğer bir iktisat kitabıdır. Kitap bir iktisadi teori kitabı olmaktan ziyade bir iktisat tarihi kitabını andırmaktadır (Berkes 1975: 333). Eser, giriş, sonuç ve dokuz bölümden oluşmuş, ilkel toplumların iktisat anlayışından İngiltere'de demiryolların etkisine kadar ki iktisat konularınna değinmişstir (Tütengil, 1965: 146). Ayrıca iş bölümü, ticaret, mal, sermaye, para, banka, icatlar ve borçlanma konularına değinmiştir (Şener 1994: 219).

1860 senesinde yayımlanan ülkenin ilk özel gazetesi olan Tercüman-ı Ahval'in değindiği konulardan biri de ekonom ilmi olmuştur. Gazetede Mehmet Şerif Efendi tarafından yazılan "Ekonomi Politik IIIminin Tarikiyle Hudud-ı Tabiyesinin Tahdidi Beyanındadır" başııkı makaleyle ekonomi ilmi hakkında okurlara bilgi verilmiştir. Şerif Efendi, bu ilmin Avrupa'nın tüm eğitim kurumlarında öğretildiğini vurgulamıştır. Ekonomi ilminin, insanoğlunun ürettiği malların etkilerini, aralarında oluşturdukları ilişkileri, bu ilişkilerin cemiyeti harab edip zarar verecek hastalıkları araştırdığını ve bunlara çözüm ürettiğini belirtmiştir. Ekonomi İlmi'nin başlangıç tarihini İngiliz Adam Smith'in 1776 senesinde basılan üç ciltlik eseri göstermiştir. Eserin Fransızca'ya çevrilerek bu ilmin dünyaya yayıldığını, çeşitli milletlerden âlimlerin eserler telif ettiklerini belirtmiştir (Şerif Efendi, 1861a: 3). Sonraki sayıda ise Şerif Efendi, "IImi Emvali Milliye" olarak tercüme ettiği ekonomi ilminin özelliklerini anlatmıştır. Bu ilmin üretim, bölüşüm ve dağıtım, mübadele ve tüketim olarak dört bölümden oluştuğunu ifade etmiş ve ekonomi ilminin içeriği hakkında okurları bilgilendirmiştir. Şerif Efendi, bir ülkenin bu ilmin kurallarını benimsediği takdirde servet ve ticaret konusunda ilerleyip zenginleşeceğini vurgulamıştır. Bu konuda İngiltere'yi örnek vermiş ve İngiltere'nin serbest iktisat düşüncesini benimsediği için geliştiğini belirtmiştir (Şerif Efendi 1861b: 2).

1862 senesinde yayımlanan Mecmua-i Fünun'un bilgi verdiği konulardan biri de ekonomi ilmiydi. Ohannes Efendi tarafından derginin 2 ve 6. sayılarında yayımlanan “IIm-i Servet-i Milel” adlı makalede ekonomi ilmi okurlara tanıtılmıştır. Ohannes Efendi, makalede ekonomi ilminin temeline ait çalışma, ihtiyaç, servet, üretim, iş bölümü, mübadele, sermaye, para, bölüşüm, tüketim, fayda ve değer gibi kavramları serbest iktisat düşüncesi doğrultusunda açıklamıştır. Bir ülkede üretimin fazlalığını zenginliğini 
ölçütü olarak gören Ohannes Efendi, ülke kalkınması için üretimin artırılmasını ve ticaretin serbestleştirilmesini istemiştir (Ohannes Efendi, 1862: 86-92; 243;249).

1860'ıların diğer yayım organı olan Tasvir-i Efkâr'da Şinasi, Şerif Efendi'nin “ïlmi Emval-i Milliye" olarak çevirdiği ekonomi kitabının neşredildiğini belirtmiş ve bu bahisle ekonomi ilmi hakkında okurlarına genel malumat vermiştir. Şinasi, ekonomi ilminin toplumun tüm servetlerinin nasıl oluştuğunun sebebini açıkladığını ifade etmiş ve servetten istifadenin nasıl olması gerektiğini incelediğini belirtmiştir. Bir devletin gelişmişliğinin bu ilmi bilip bilmemesine bağlı olduğunu ifade etmiş ve özellikle bürokratların bu ilmi öğrenmesini istemiştir. Hem ferdin hem de toplumun gelişmesinin servetinin çokluğuna bağlı olduğunu ifade etmiştir. Bu nedenle servetin artırılması ve ülkenin zenginleşmesi için bu ilmin kanunlarının bilinmesini ve ilme göre hareket edilmesini istemiştir (Şinasi 1863: 1).

Çalışmanın içeriğini oluşturan tefrika kitaplarının yazarlarından biri olan Mehmet Şerif Efendi, Mekteb-i Mülkiye'de ekonomi dersi vermiştir. Mülkiye'de verdiği ders notlarını 1863 senesinde "IIm-i Emval-i Milliye" adıyla neşretmiştir (Fındıkoğlu, 1946: 22). Şerif Efendi, eserinde ülkenin sanayi ve ticarette geri kalmasından dolayı bazı kişilerin Osmanlı'nın Avrupa sanayisini taklit ederek sanayileşmede başarısız olacağını ve bu nedenle ülkenin sanayileşme yerine sadece ziraatta gelişmesini eleştirmiştir (Kurdakul, 1990: 58). Milli servetinin kaynağını anlamayan milletlerin kısa süre içerisinde servetlerini kaybettiklerini ifade etmiştir. İspanya'nın Amerika'yı keşfinden sonra ülkelerine getirdiği yüklü miktarda altın ve gümüşten sonra servetin altın ve gümüş olduğunu düşünerek milli sanayi ve ticareti bıraktıklarını ifade etmiş ve bu nedenle milli servetinin zamanla harice aktığını belirtmiştir. Bir ülkenin milli servetinin ziraat, sanayi ve ticarette gerçekleşen üretim olduğunu vurgulamıştır (Kurdakul, 1990: 59). Tercüme Odası'nda çalışan Şerif Efendi'nin, dönemin önemli yayımları olan Tercüman-ı Ahval ve Mecmua-ı Fünun'da ekonomi yazıları da çıkmıştır (Şener, 1994: 220).

Diğer tefrika kitabının yazarı olan Şuray-ı Askeri memurlarından Mehmet Midhat, 1869 senesinde Alman iktisatçı Hobner'in Fransızcaya "Halka Dair Ekonomi Politik Kitabı" ismiyle çevirilen kitabını "Ekonomi Tercümesi: Fenn-i Idare" adıyla Türkçeye çevirmiştir (Kurdakul, 1990: 57). Kitabın yarıya yakın bölümü Terakki gazetesinde neşredilmiştir (Şener, 1994: 224). Mehmet Midhat, kitabı yazma amacını ülkede yayımlanan iktisat kitaplarının eğitim almış kimselerin anlayacağı derecede olduğunu ve bu kitapların halkın okuyup anlayamayacağını ifade etmiş ve bu nedenle bu kitabı okuması az olan halkın anlaması için yazdığını belirtmiştir (Fındıkoğlu, 1946: 23-24). İktisadi terimlerin Türkçe karşılıklarını yazmaya özen göstermiş ve birçok Türkçe iktisadi terim üretmiştir. Örneğin rant kelimesine karşılık kesim sözcüğünü kullanmıştır (Berkes, 1975: 333). Eserde gerek işçi gerekse de küçük esnafın bankalardan yararlanmasının imkânsız olduğunu belirtmiş, bu nedenle işçi ve küçük esnafın bir araya gelip kredi şirketleri kurarak kredi sorunlarını çözebileceği ifade edilmiştir (Kurdakul, 1990: 58). Halkın tembelliği ve lüzumsuz harcamalarını fakirliğini nedeni olarak göstermiş ve bundan kurtulmak için ise tasarruf, çalışma ve şirketleşmeyi önermiştir (Kurdakul, 1990: 58). Eserde, makinanın faydaları, zengin ile fakir, yoksulluk ve bunun sebepleri gibi konulara da değinilmiştir (Kurdakul, 1997: 120). 


\section{Mehmet Efendi' nin Terakki'de Yayımlanan Ekonomi Tercümesi: Fenni İdare Kitabının Tefrikası}

Mehmet Mihtat'ın 1869 senesinde yayımlanan kitabı aynı senede Terakki gazetesinin sayfalarında tefrika edilmiştir. Aşağıda Terakki'nin farklı sayılarında tefrika edilen kitabın içeriği incelenmiştir. Mehmet Midhat, Terakki’nin 81. sayısında ülkede modern iktisat bilimi öğreten kitapların çok az sayıda olduğunu belirtmiş, yayımlanan kitapların ise halk tarafından anlaşılmayacak şekilde ağır bir dille yazıldığını ifade etmiştir. Halkın bu kitaplardan istifade etmesi için bir ekonomi hocasına müracaat etmek zorunda kaldığını ve kitaplardan yetetince istifade edemediğini dile getirmiştir. Ayrıca ülkede ekonomi ilmini halka anlatacak ekonomi hocasının da az olduğunu belirtmiştir. 19. yüzyılda önemli bilim haline gelen ekonomi ilmini halkın anlayacağı Arapça ve Farsça terimlerinden arındırıımış Türkçe kitabının yayımlanmasının zorunlu olduğunu ifade etmiş ve Terakki gazetesinde bu doğrultuda Alman iktisatçı Otto Hübner'in kitabınının Fransızca aslından Türkçeye çevireceklerini belirtmiştir. Kitabın küçük boy olup sorucevap formatında hazırlandığınından faydalı olacağını ve kitabı biraz okuma yazma bilen halkın anlayacağı basit bir Türkçe ile neşredileceğini ifade etmiştir. Mehmet Mithat, eserinde öncelikle çalışmanın ne olduğunu anlatmıştır. İnsanın tarlarını işleyip çift sürdüklerini, ekip biçtiklerini, ormanlarda avcılık ettiğini, nehirlerde balıkçılık yaptığını, demir ve tahtayı işledikerini, bez ve kumaş dokuduklarını belirtmiş ve bu gibi faaliyetlerin çalışma olduğunu ifade etmiştir. İnsanın günlük intiyaçlarının temini ancak çalışmak sonucu elde ettiğini ve bunların elde edilmesi için çalışmak zorunda kalındığını vurgulamıştır. İnsanın çalışarak birçok fayda ve kazanç elde edeceğini belirtmiştir (1869a: 1-3). Mehmet Mithat, 82. sayıda ise tembellik meselesine değinmiştir. Çalışmayan kişilerin gezip dolaştıklarını ancak sonraki günlerde zorunlu intiyaçlarını temin edemeyeceğini belirtmiştir. Zengin bir insanın bile çalışmazsa kısa bir sürede zorluklar yaşayacağını ve bu doğrultuda zenginlerin de çalışması gerektiğini vurgulamıştır. İnsanoğlunun çalışmadığı takdirde zengin ve fakir herkesin aç kalacağını belirtmiş, geçim kaynaklarının üretilemeyeceğini ifade etmiştir. Çalışmadıkça paranın elde edilemeyeceğini ve insanın bu hayatta geçimini sağlayamayacağını belirtmiştir. Çalışmamanın genel değil bireysel olduğu takdirde bu kişinin geçim kaynaklarını temini için başkalarından dilenmesi gerekeceğini ve dilenmenin çalışmaktan daha zor olduğunu vurgulamıştır (1869b: 3).

Mehmet Midhat, 83 sayıda "taksim-i amel'i bir kitap örneği vererek anlatmıştır. Yazılan bu küçük ekonomi kitabın önce yazar tarafından yazıldığını sonra matbaada onlarca kişinin iş bölümü gerçekleştirerek kitap halinde çoğaltıldığını ifade etmiştir (1869c: 2). Mehmet Mithat, 84. sayıda bu kitabın yazar ve matbaacılardan başka kağıdın imali, ilmin öğrenilmesi, kitabın postalanması, ve kitabın ulaştırılmasında yolların yapımı sürecinde de iş bölümünün gerçekleştiğini vurgulamıştır. Bütün bu iş bölümü olmadığı takdirde kitabın yazardan okura ulaşma sürecinin gerçekleşmeyeceğini ifade etmiştir. İş bölümü olmayıp da sadece bir kişinin kitabı yazması, basması, kitabı basan makineleri icat etmesinin imkansız olduğunu ve kitabın asla oluşamayacağını belirtmiştir (1869d: 4). 86. sayıda bir malın üretiminde farklı kişilerin iş paylaşımı gerçekleştirerek çalışmasına taksim-i amel yani iş bölümü dendiğini belirtmiştir. Bir 
kişinin kendisinin çoğu kez amel ettiği bir eylemi gerçekleştirmesiyle bir yetenek elde edeceğini ve bunun sonucunda o işte bir ustalık kazanacağını ifade etmiştir. Kitabın basılmasında çalışan mürettib mesleğini ne kadar sık tekrar ederse yada ekonomi ilmini öğrenen öğrenci ne kadar çok tekrar edip dersine çalışırsa o derecede usta olacağını vurgulamıştır. İş bölümünün sadece işte uzmanlaşmayı sağlamadığını aynı zamanda faydalı alet ve makinaların üretilmesini gerçekleştireceğini ve farklı kişilerin yeteneklerin bir araya gelmesiyle bunun gerçekleştiğini vurgulamıştır (1869e: 3). Mehmet Mithat, 87. sayıda ise iş bölümüyle gerçekleştiren makinalar sayesinde ucuz üretimin gerçekleştirilmesinin mümkün olduğunu vurgulamıştır. Kitap örneğine tekrar değinen Mehmed Midhat, basma makinaların icat edilmesiyle çok sayıda kitabın basılması sonucu kitabın ucuz satıldığını ifade etmiştir. Kağıdı üreten makinaların pahalı olmasına karşın makinaden elde edilen kağıdın ucuz elde edilmesinin taksim-i amelle gerçekleştiğini belirtmiştir. Bu taksim-i amel sayesinde yüzlerce yetenekli insanın emeğiyle ucuz üretimin gerçekleştiğini ifade etmiştir. İş bölümü gerçekleşmeseydi bir kitabın basılmasının hem uzun süreceğini hem de pahalı üretileceğini belirtmiştir. Kitabın üretiminin maliyetli ve meşakkatli olacağından bu bilgiden istifade edecek kişi sayısının az olacağını ve bilginin yayılamayacağını dile getirmiştir. İş bölümü sayesinde kitabın çoğalması sonucu medeniyetin daha da geliştiğini ve bugünkü medeniyetin iş bölümü sonucu olduğunu ifade etmiştir (1869f: 3-4).

Mehmet Midhat, 89. sayıda mübadele konusunu anlatmıştır. Çiftçinin sadece ziraatla, dülgercinin tahtayla, kunduracının çizmeyle ve terzinin dikişle uğraştığını ve zanaatların çok müşkül işler olduğunu ve bu işi öğrenmek için uzun süre emek verdiklerini vurgulamıştır. Bu zanaatkarların bazen diğer zanaatçıyla işbölümü gerçekleştirdiğini kunduracının lazım olan takım aletini dülgerciden aldığını ve dülgercinin de kendi ayakkabılarını kunduracıdan satın aldığını belirtmiştir. İnsanın işlerini aralarında taksim-i amel ettiğini ifade etmiş, eğer bu iş bölümü gerçekleşmediği takdirde kunduracının bir günde yaptığı üretimi bir haftada elde edeceğini belirtmiştir. Ayrıca kunduracının lazım olan bir sofra takımını üretmesi halinde de bunun daha maliyetli elde edeceğini bildirmiştir. Bir çiftçinin sadece buğday ürettiğini ancak kendisine lazım olan elbise, ayakkabı, sofra ve iskemlesinin taksim-i amel sayesinde elde ettiğini, diğer zanaatkaların da taksim-i amel sonucu lazım olan intiyaçları başka kişilerden karşıladığını belirtmiştir (1869g: 4). Mehmet Mithat, 90. sayıda taksim-i amelin, bir kişinin üretimi gerçekleştirdikten sonra kendisine lazım olmayan kısmı başkalarıyla mübadele ederek kendisine lazım olan intiyaçları temin etmeyi lüzumlu kıldığını belirtmiştir. Çiftçinin ürettiği malın tüketmediği kısmını kunduracıya, kunduracının ise çizmelerini çiftçiye verdiğini belirtmiş, gerçekleşen bu alışverişe mübadele dendiğini bildirmiştir. Kunduracının bir günde ürettiği ayakkabıyı dülgercinin bir haftada üreteceğini aynı zamanda dülgercinin bir günde yapacağı sofra takımını da kunduracının bir haftada üreteceğini bu nedenle kunduracının sofra takımını dülgerciden dülgercinin ise ayakkabıları kunduracıdan mübadele ettiklerinde, mübadele sonucunda ikisininde yedişer günde üreteceği bir ürünü bir günde üreteceğini ve altışar günde çok daha fazla üretim gerçekleştireceklerini belirtmiştir (1869i: 4). Mehmet Mithat, 92. sayıda insanoğlunun tüm geçim kaynağını kendisi gerçekleştiği takdirde gerçekleşecek faydanın az olacağını ve birçok işlevi de gerçekleştiremeyeceğini belirtmiştir. Mübadele 
gerçekleşmediği takdirde insanoğlunun lazım olacağı tüm gereksinimleri kendisinin tedarik etmesinin imkansız olduğunu vurgulamıştır. Taksim-i amel ve mübadele sonucu insanoğlunun gereksinim duyduğu tüm intiyaçlarını hem kalite hem de ucuz olarak olarak elde edeceğini ifade etmiştir (1869k: 2-3).

Mehmet Midhat, 94. sayıda mübadele sayesinde ülkelerin üretemediği birçok ürünü uzak ülkelerden mübadele ettiğini belirtmiştir. İtalya'da limon ve zeytin, Amerika'da pamuk ve kahve, Almanya'da elma ve ketenin üretildiğini ifade etmiş ve bu ürünlerin tüm bölgelerde üretilmesinin imkansız olduğunu vurgulamıştır. Mübadele sayesinde ülkelerin üretemedikleri eşyaları uzak bölgelerden temin ettiğini belirtmiştir. Amerika'nın limon intiyacını mübadele sonucu İtalya'dan elde ettiğini bildirmiştir. Mübadele sonucu Allah'ın (cc) yeryüzünün farklı bölgelerine verdiği hediyelerden tüm insanların istifade edip ve bunlardan faydalandığını ifade etmiştir. Mübadele sonucunda ülkeler muhtaç olduğu eşyaları komşu ülkelerden hatta uzak ülkelerden temin ettiği için ülkelerin mübadeleden kazanç sahibi olduklarını belirtmiştir. Eğer fayda elde edilmeseydi bölgelerarası mübadelenin olmayacağını ifade etmiştir (1869l: 3). Mehmed Mithat, 95. sayıda mübadelenin ülkelere yada kişilere olan faydasını şu örnekle açıklamıştır. İki öğrencinin birisinde 2 kalem diğerinde de 2 kalem traşı olsa ve öğrenciler bunları aralarında mübadele ettiği takdirde kendisinde olmayan şeye sahip olacaklarını vurgulamıştır. Bunun gibi birçok örneğin verilebileceğini, uzak iki ülke arasındaki mübadelenin böyle olduğunu, bir ülkenin ipeği diğer ülkenin ise limon ve elmaları olduğunu ve bunları mübadele ederek olmayan şeyi elde edeceklerini ifade etmiştir. Mehmet Mithat tüm ülkelerin üreteceği ürünlerde de mübadelenin gerçekleşeceğini vurgulamıştır. Çeliğin tüm ülkelerde üretilmesine karşın çoğunlukla İngiltere'den mübadele edildiğini belirtmiştir. Her evde ekmek pişirilmesine karşın ekmeğin fırıncıdan alındığını, bunun nedenini ise ekmeği evde üretmekten ziyade fırıncıdan daha ucuz alınması olduğunu ifade etmiş, İngiltere'den çeliğin mübadele edilmesinin de böyle olduğunu belirtmiştir. İngiltere'den çeliğin ucuz üretilmesiyle buradan çeliğin alınması sonucu ülkelerin çeliği üreteceği sermayeyi uzman olduğu sektörde kullanarak bundan daha fazla istifade edebileceğini vurgulamıştır (1869m: 4). Mehmet Mithat, 98. sayıda pahalı üründen az kimselerin istifade edeceğini, ucuz üründe ise istifade eden kişilerin fazlalaşacağını ve birçok insanın ihtiyacının karşılanacağını ifade etmiştir. Mübadele sayesinde uzak bölgelerden ucuz malın temin edilmesiyle insanların daha fazla fayda sağlayacağını belirtmiştir. Mübadele olmayan yerde taksim-i amelin gerçekleşmeyeceğini bu doğrultuda orada barbarlığın hüküm süreceğini ifade etmiştir. Farklı bölgelerden ucuz mal temin etmenin ilerleme açısından önemli olduğunu ve ucuz bölgelerde mal teminin maliyetli olmasına karşın bunu kolaylaştırmak için birçok ulaşım aracın geliştirildiğini ve maliyetlerin düşürüldüğünü belirtmiştir. Bugünkü asırda ulaşım maliyetlerinin malın maliyetinden düşük bir oran teşkil ettiğini vurgulamıştır (1869n: 1-2).

Mehmet Mithat, 99. sayıda para konusuna değinmiştir. Para ile insanoğlunun lazım olan zorunlu intiyaçlarını satın aldığını ve para olmadığı sürece bunları satın alamayacağını belirtmiştir. Paranın bir değişim aracı olduğunu belirten Mehmet Mithat, parayla kunduracının fesciden kundura almadan intiyacını giderdiğini, mübadeleyi 
kolaylaştırdığını ve eğer para olmasaydı fescinin fesini satmak için ihtiyaç hissetmediği kundurayı almak zorunda kalacağını ifade etmiştir (1869o: 2). 100. sayıda ise mübadele aracı olarak önceleri birçok değerli şeyin kullanılmasına karşın bunlar arasında taşınması kolay olan altın ve gümüşün mübadele aracı olarak kullanılmasının tercih edildiğini ifade etmiştir. Altın ve gümüşün bozulmazlığı ve değerinden dolayı tüm bölgelerde kabul gördüğünü, bunun sonucu mübadele aracı olarak tüm ülkelerde kullanıldığını belirtmiştir. Altın ve gümüşün bir mal olarak talep edilmediğini, bu madenlerin ticareti kolaylaştırdığı için talep edildiğini ve bu nedenle mübadelede altın ve gümüşün kullanıldığını dile getirmiştir (1869p: 6). Mehmet Mithat, 102. sayıda altın ve gümüşün uzak bölgeler arası ticareti kolaylaştırdığını ve altın ve gümüş sayesinde insanların tüm zorunlu ihtiyaçlarını kolayca temin ettiğini belirtmiştir. Altın ve gümüşün sadece mübadeleyi kolaylaştırmadığını aynı zamanda servet biriktirme aracı olduğunu ve insanların servetlerini altın ve gümüş olarak biriktirebileceklerini ifade etmiştir. Uzak bölge ticaretinde altın ve gümüşün taşınması kolay olduğundan ve herhangi bozulmanın gerçekleşmemesinden dolayı tercih edildiğini ve birkaç sene saklanmasıyla değerinin değişmediğini vurgulamıştır (1869r: 3)

Mehmet Mithat, 108. sayıda sermaye ve faize değinmiştir. Sapan sahibi bir çiftçinin sapanla toprağını işlerde daha fazla fayda ettiğini belirtmiştir. Toprağı olup da sapanı olmayan çiftçinin sapanı olan çiftçiden ödünç alması durumunda sapan sahibinin bu ödünç vermede sapanın kendisine lazım olduğundan zararlı çıkacağını ifade etmiştir. Bu nedenle sapanı olmayan çiftçi sapan sahibine belli bir ücret vererek sapan sahibinin zararını karşıladıktan sonra sapanı elde edeceğini bildirmiştir. Toprak için de bu durumun geçerli olduğunu ve toprak sahibisinin arazisini bu şekilde başkalarına kiraladığını ifade etmiştir. Para için aynı durumun geçerli olacağını belirten Mehmet Mithat, sermaye sahibi kişisinin sermayesiyle kendi işlerini büyütüp daha da istifadesini gerçekleştirecekken bunu başkasına vermesinin zor olacağını verse bile kendi kazancının telafi edilmesi isteyeceğini verdiği sermayeye karşı daha fazla isteyeceğini bu fazlalığa para meselesinde faiz, toprak meselesinde ise kira denildiğini belirtmiştir (1869s: 7). 110. sayıda ise Mehmet Mithat sermaye sahibinin sermayeden fayda gördüğünü, sermayenin bir mülk olduğunu, bundan dolayı fayda görmesi hakkının olduğunu, ancak insanın emek verdiği sermayeden fayda alabileceğini ifade etmiştir. Sapan sahibi çiftçinin sapanı saklarsa bundan fayda edemeyeceğini, lazım olan çiftçilerin işi görülmediğinden üretimin artmayacağını ancak sapan sahibi sapanını kiraya veririse üretimin artacağını ve kendisinin de bundan kazanç elde edeceğini belirtmiştir. Sapan sahibinin sapanını daha önceki emekle elde ettiğini ve kazandığı para ile aldığından aldığı ücretin sapanın çalıştırma ücreti olduğundan hakkı olduğunu vurgulamıştır (1869t: 3-4). Mehmet Mithat, 114. sayıda faiz ve kira konusuna devam etmiştir. Sermaye ve arazi konusundaki durumun sapan hakkındaki durum gibi olduğunu belirtmiştir. Sermaye sahibinin ödünç verdiği eski çalışmasının eseri olduğunu ve buna karşılık aldığı faizin eski çalışmanın mükafatı olduğunu ifade etmiştir. Bu mükafatı almak için sermayenin ödünç olarak verilmesi gerektiğini belirtmiştir. Sonra faiz oranının artış ve azalışların nedenine değinmiştir. Faizin sermaye sahibinin eski çalışmanın ürünü mükafatı olduğuna tekrar ifade eden Mehmet Mithat, sermayeden alınan faiz miktarının alet ve araziden alınan kira gibi gelirden az olduğunu belirtmiştir. 
Çünkü paranın herhangi bir yıpranma payının olmadığını ifade etmiştir. Paranın geriye ödenme olasılığı ne kadar yüksekse faiz oranlarının o derece az olduğunu ayrıca ödünç karşılığında rehin alınırsa faizin yine az olacağını ifade etmiş, eğer teminat yoksa paranın geri ödenme riski nedeniyle faiz oranının yüksek olacağını söylemiştir. Ayrıca faiz oranın borç alacak kişinin kredisine göre değişebileceğini çalışkanlığı ve ustalığı etklenlerin faiz oranını düşüleceğini belirtmiştir. Faiz oranlarını ayrıca devletin usul ve yöntemlerine bile etkide bulunacağını ifade etmiş, sermayenin geri ödenmesi hususu güven verici kanunlarla teminat altına alındığında faiz oranlarının düşük olacağını belirtmiştir (1869u: 7).

Mehmet Mithat, 116 sayıda fabrika, zanaatkar ve işçi meselesine değinmiştir. Ham demirin faydasının az olduğunu ancak bu demirin fabrikalarda işletildiği zaman faydasının ve değerinin artacağını ifade etmiştir. Demirden yapılan aletler olmasaydı insanoğlunun yaşamın zorlaşacağını ve toprakların işıenmesinin meşakkatli olacağını belirtmiştir. Ayrıca pamuğun ham olarak faydasının da az olduğunu, ama pamuğun fabrikalarda işletmesiyle elde edilen iple birçok dokuma ürünün üretildiğini ve insanların soğuktan korunduğunu vurgulamıştır (1869v: 6).

\section{Mehmet Șerif Efendi'nin Tercüman-ı Ahval'de Yayımlanan IIlm-i Emval-i Milliye Kitabının Tefrikası}

Mehmet Şerif Efendi Mekteb-i Mülkiye'de verdiği ders notlarını 1863 senesinde "illm-i Emval-i Milliye" başlığıyla neşretmiştir. Kitap yayımlamadan önce Tercüman-ı Ahval'in sütunlarında da 1861 senesinde tefrika edilmeye başlanmıştır. Şerif Efendi, gazetenin 126. sayısında “IIm-i Emval-i Milliye"hin servetin oluşması ve refahın görülmesiyle uğraşan bir ilim olduğunu ve bu ilim doğrultusunda hareket etmeyen milletlerin zamanla gerileyip ortadan kalktıklarını ifade etmiştir. Bu ilmi benimseyen milletlerin nüfus olarak ne kadar fazla olsa bile medeniyetten mahrum oldukları için bunların zorluk göreceğini belirtmiştir. Bu milletlerin sahip oldukları kaynakları işletemediklerinden dolayı ortadan kalktığını eğer sahip olduğu servetleri istifade için çalışırlarsa medeniyet derecesinin artıp gelişeceklerini ifade etmiştir. İnsanoğlunun yeryüzünde ilk olarak hayvanlardan istifade etmeyi öğrenip ve bunları otlamak için göçebe toplumlar halinde yaşadıklarını belirtmiş, öncekilerine göre bir derece medeniyet yolunda ilerlediklerini ifade etmiştir (1862a: 3-4). Şerif Efendi, 127. sayıda insanoğlunun doğada göçebe gibi dolaşmalarından sonra belli bir yerde ikamet ederek ziraata başladıklarını, irili ufaklı sahip olduğu hayvanlardan istifadesini artırarak ziraatını geliştirdikten sonra insanoğlunu cemiyetin üçüncü aşaması olan devletler kurduklarını belirtmiştir. Ülum ve fünun yolunda ilerleyerek her çeşit zanaatla meşgul olmaya başladıklarını ve bu doğrultuda birçok makine icat edip üretimi çoğalttıklarını ifade etmiştir. "IIm-i Emval-i Milliye"nin bir milleti servet ve medeniyet yolunda ilerlettiğini belirtmiştir. Bir ülkenin gelişmişiğinin sanayi ve ticaret sektöründen gelişimine bağlı olduğunu ifade etmiş, Kuzey Amerika Birliği'nin servet ve refah yolunda gösterdiği gelişmesinin bunun sonucu olduğunu, Mısır ve Şam bölgelerinin gelişememesinin nedeninin de bu olduğunu vurgulamıştır. Üretimini sanayide özel sektörle gerçekleştiren ülkelerin kalkındıklarını ifade etmiş, ziraat, sanayi ve ticaret gibi konularda kısıtlamaların olduğu ülkelerle ile bu 
tarz kısıtlamaların olmadığı ülkeler arasında gelişmişlik farkının olduğunu belirtmiştir. Herhangi bir kısıtlamanın olmadığı ülkelerde ticaret, sanayi ve ziraatta ilerlemenin görüldüğünü vurgulamıştır (1862b: 3-4).

Şerif Efendi 132. sayıda "ilım-i Emval-i Milliye'nin nazari ve ameli olarak ikiye ayrıldığını belirtmiş, bu ilmi nazari ve ameli olarak benimseyen ülkelerin sanayisinin kalkınmış bir seviyede olacağını ve bu doğrultuda servetin artacağını ifade etmiştir. Dünya başlangıcında imar, sanayi ve ziraat konusunda pek gelişmemişken şimdi eskisine göre ilerlemiş olduğunu belirtmiştir. Kaynakların İlm-i Emval-i Milliye doğrultusunda kullanan ülkeler ile kullanmayan ülkeler arasında bir fark olduğunu ve İlm-i Emval-i Milliye doğrultusunda servetlerinden istifade edemeyen ülkelerin geri kalmaya mahkum olduğunu belirtmiştir. Servet sahibi olmak için olması gereken hırstan başkalarının olumsuz şekilde etkilenmeyeceğini bilakis hırsın birçok yenilik getireceğini ve üretimin ucuz elde edilmesini sağlayacağını ifade etmiştir (1862c: 2-3). Şerif Efendi, 134. sayıda İlm-i Emval-i Milliye'nin toplumun servet kaynaklarından istifade etmek için bunların toplumun yararına getirilmesinin amaçlandığını ifade etmiştir. İlm-i Emval-i Milliye ilmine göre servet kaynağının para olmayıp üretim olduğunu, paranın üretimi vücuda getiren bir nesne olduğunu belirtmiş̧tir. Bir ülkede üretim gerçeklemediği sürece orada servetin oluşamayacağını vurgulamıştır (1862d: 3-4). 136. sayıda Fransa'da şarabın ihraç edilmemesi için belirli engellerin konulduğunu, bunun sonucunda üzüm fiyatının azaldığını ve bu doğrultuda birçok bölgede üzümün tarlada çürümüş olarak bırakıldığını belirtmiştir. Yine İngiliz kolonilerinde diğer Avrupa ülkelerine gümrük resmi konulmasıyla üretilen kahvelerin çoğunun denize atıldığını ifade etmiştir. Bu nedenle bir ürünün değeri ve üretimine herhangi bir kısıtlamanın olumsuz bir sonuç doğurduğunu ve üretimin azaldığını belirtmiştir. Servetin asıl kaynağının para olmadığını bilakis üretim olduğunu bir daha vurgulamıştır (Efendi, 1862e: 2-3).

Şerif Efendi 137. sayıda mülkiyet konusuna değinmiştir. Servetin oluşması için verimli toprak, alet ve makinaların sadece bir araç olduğunu servetin asıl kaynağın insanın say $u$ ameli olduğunu belirtmiştir. İnsanoğlunun ziraat ve sanayide bilgi birikimini artırıp alınteriyle çalışarak kazanç ve servet sahibi olabileceğini ifade etmiştir (1862f: 2-3). 147. sayıda insaoğlunun say u amel doğrultusunda çalıştırılması konusunda gayret gösterilmesini istemiştir. İnsanoğlunun çalışmaya teşvik edilerek sanayi ve fununda gelişmesinin sağlanmasını ve yapılacak teşebbüslerde olumlu neticelerin alınacağını belirtmiştir. Bir insanı çalışmaya sevketmenin sanayi ve ilim konusunda say u amel etmesiyle bundan gerekli faydanın elde edileceğini ifade etmiştr. Göçebe olmayan toplumları iskan ederek bunlara belirli zanaatların öğretilmesiyle bu kişilerin bu zanaatlarını öğrendikten sonra mesleklerinde daha gelişmiş alet ve araçları tedarik edeceğini vurgulamıştır. Ayrıca göçebeleri iskan edip zanaatın öğretilmesiyle göçebelerin kanuna uyan bir topluma dönüşeceğinden ülkede asayiş ve güvenliğin de sağlanmış olacağını belirtmiştir (1862g: 3-4). Şerif Efendi, 153. sayıda bir kişinin kendi emeğiyle elde ettiği şeye sahip olmasının o ülkede imarın ve servetin gelişmesini etkileyeceğini ve servetin kanunlarla güvenceye alınmasının refah açısından önemli olduğunu vurgulamıştır. Filan dükkânın Rahim beye, filan hamamın Kerim efendiye, filan değirmenin Dimitri'ye ait olduğunu hükmedecek kanunla bu malların mülkiyeti 
güvence altına alındığını ve bunların miras ile varislerine bırakılmasıyla o ülkede servetin artacağını belirtmiştir (1862h: 3-4). 177. sayıda mülkün emniyet altına alınmasının üretim için önemli bir tesir olduğunu ve bunun sonucunda orada sanayinin gelişip servet yolunda önemli adımların görüleceğini belirtmiştir. İnsanoğlunun eşyaların mülkiyetine sahip olmayıp da tüm mülkün ortak kullanılmasıyla o ülkede imar ve sanayinin gelişmeyeceğini ifade etmiştir. Yönetimin iskan olunan bölgelerde kişilere bedava toprak verdiğini ama toprağın bu kişilerin mülkiyetine geçtikten sonra say u amel ederek verimini artırıp üretim gerçekleştirdiklerini belirtmiştir. İnsanoğlunun mülkiyeti elinde olan eşyalardan istediği gibi kullanma serbestliğinin olmasının buralardan istifadenin artırıldığını vurgulamıştır (1862i: 2).

\section{Sonuç}

Osmanlı Devleti'nde 1830'lu yıllardan itibaren ülkede ikamet eden yabancı vatandaşlar tarafından serbest iktisat düşüncesine ait görüşler öne sürülmeye başlanmıştır. Bu yıllarda ülkede görülen basın kurumu sayesinde bu düşünce kamuoyunda verilmiş ve yayımlanan yazılarla halkın modern iktisat ilmini öğrenmesine çalışılmıştır. Bu dönemde ülkede ikamet eden ve serbest iktisat düşüncesinin benimseyen Blak Bey ülkenin resmî gazetesinin Fransızca bölümü olan Le Moniteur Ottoman başına getirilmiş, gazetede serbest iktisat düşüncesi doğrultusunda yayım politikası gütmüştür. Blak Bey'in devletin resmî gazetesinde bu düşünceleri aktarmasıyla Osmanlı Devleti'nin de ülkede modern iktisat ilminin yayıımasını ve bu ilmin halka tarafından öğrenilmesini destekleğini göstermektedir.

Ülkede serbest iktisat düşüncesinin girmesiyle bu düşüncenin halka öğretilmesi konusunda Batı kaynaklı ilk ekonomi kitapları da yayımlanmıştır. İktisat kitaplarının yayımlanmasıyla birlikte bu kitapların tefrikası dönemin gazetelerinde yayımlanmaya başlanmış ve ekonomi ilmi konusuda birçok makale yayımlanmıştır. Ülkede yayımlanan iktisat kitapları Avrupa ülkelerinden yayımlanmış kitapların tercümesi olarak bilinmesine karşın yazarlar tercüme ederken kitapların yöntemini değiştirmesi ve kendi görüşlerini ifade etmesiyle bu tercümeler telif-tercüme olarak adlandırılmaktadır. Osmanlı'da ilk iktisat kitabı yazarın ismi belli olmayan "Risale-i Tedbir-i Ümran-ı Mülk”" adlı eserdir. Bu eserin yayımlanmasından sonra Serendi Arşizen'nin “Tasarrufat-ı Mülkiye”si 1840 senesinde ve Sehak Abru'nun “IIIm-i Tedbir-i Menzil'i ise 1852 senesinde yayımlanmıştır. Bu iki eserle birlikte ülkede 1830'larda giren klasik düşüncesi görüşleri daha sistematik olarak işlenmiş ve bu ilmin teorileri halka öğretilmiştir.

Osmanlı Devleti'nde halka ilimlerin öğretilmesi açısında gazetelerin hizmeti kitaplardan fazla olmuş ve halk gazetelerden ilimleri öğrenmiştir. Bu nedenele yayımlanan iktisat kitapların tefrikaları ve ekonomi ilmi hakkında birçok makale gazetelerde yayımlanmıştır. Illk iktisat kitabı "Tedbir-i Umran-ı Mülki”nin bazı bölümleri Takvim-i Vekayi gazetesinde yayımlanmıştır. 1852 senesinde Ceride-i Havadis, ekonomi ilmi hakkında makaleler yayımlamış ve halkın anlayacağı bir dilde basit bir ekonomi kitabını matbaasında bastırmış ve okurlarına ulaştırmıştır. 1861 senesinde Mehmet Şerif Efendi Tercüman-ı Ahval'de ve 1862 senesinde ise Ohannes Efendi Mecmua-ı 
Fünun'da çeşitli makalelerle bu ilmi halka öğretmeye çalışmışlardır. Şinasi de 1863 senesinde Şerif Efendi'nin "IIIm-i Emval-i Milliye" kitabının yayımlanmasından dolayı Tasvir-i Efkar gazetesinde ekonomi ilmi hakkında okurlarına bilgi vermiştir.

Gazetelerde yayımlanan iktisat kitaplarının tefrikası ise Şerif Efendi tarafından yazılan tefrika edildikten sonra 1863 senesinde basılan "Illm-i Emval-i Milliye" ile 1869 senesinde Mehmet Mithat tarafından yazılan "Ekonomi Tercümesi: Fenn-i Idare" başlıkı makalelerdir. Şerif Efendi'nin eseri 1861 senesinde Tercüman-ı Ahval gazetesinde, Mehmet Mithat'ın eseri de 1869 senesinde Terakki gazetesinde tefrika edilmiştir. İki eserin tefrikası yarıda kalmış ve kitapların tamamı tefrika edilememiştir. Bu iki kitabın tefrikası ile modern ekonomi ilminden halkın haberdar olması sağlanmış ve bu ilim halka öğretilmeye çalışılmştır. Tefrika edilen eserlerin karşıklıklı konuşma şeklinde yazılan kitaplardan seçilmesiyle bu tefrikalarla ekonomi ilminin halka öğretilmesi amaçlanmıştır. Şerif Efendi'nin eseri hoca-ögrenci konuşması şeklinde öğrencinin sorular sorarak ekonomi hocanın da bu sorular cevap vermesi yöntemiyle tefrika edilmiştir. Mehmet Mithat'ın eseri de soru-cevap yöntemiyle hazırlanmış ve bu şekilde tefrika edilmiştir. İki eserde de ekonomi ilminin temel kavramları halkın anlayacağı şekilde verilmesine karşın Mehmet Mithat'ın tefrikası daha basit bir dille anlatılmış ve verilen örnekler halkın güncel sorunlarından verilmiştir. İki tefrika da bir ülkenin refah seviyesine ulaşması için bu ilmin bilinmesi gerektiğini vurgulamış ve ekonomi ilmi doğrultusunda teşebbüslerini gerçekleştiren ülkelerin iktisadi anlanmda kalkındıkları belirtilmiştir.

1860 senesinden sonra gazeteler hem ülkede gerçek bir kamuoyu oluşmasını sağlamış hem de halkın bilgi seviyesini artırıcı bir yayım politikası güderek halkın eğitimesinde önemli hizmetlerde bulunmuştur. Çalışmanın konusunu teşkil eden iktisat ilmi konusuda dönemin gazetelerinde birçok yazı yayımlanmıştır. Bu yayınlarda halkın iktisata olan rağbeti artırılmış ve halka modern iktisat ilmi öğretilmiştir. Ülkede eğitim kurumların gelişmemiş olması sonucu ülkede okur yazar oranının da düşük olması halkın bilgi öğrenme ihtiyacını gazetelerden elde etmesine neden olmuştur. Gazeteler de halkın bilgi seviyesini artırmayı bir vazife olarak görmüş ve yayım politikalarını bu doğrultuda sürdürmüştür. Gazetelerin kahvehanelerde yüksek sesle okunarak okur yazar olmayan kişilerin gazetelerden istifade etmesini sağlanması gazetelerin hedef kitlesinin artmasına neden olmuştur. Çalışmada elde edilen bulgulara göre dönemin iktisatçıları 1860 senelerinde gazetelerin ülkenin en önemli öğrenme aracı olmasından faydalanmışlar ve gazetelerde kitaplarını tefrika ederek bu ilmin popürleşmesini sağlamışlardır.

\section{Kaynakça}

Aydar, Metin, (2016). Risale-i Tedbir-i Umran-ı Mülki: Osmanlı Devletinde Iktisat IIImine Dair Bir Risale, Gaziosmanpaşa Üniversitesi, Sosyal Bilimler Enstitüsü, Basılmamış Yüksek Lisans Tezi, Tokat.

Balcı, Sezai, (2009). Bir Osmanlı-Ermeni Aydın ve Bürokratı: Sahak Abro, Osmanlı Siyasal ve Sosyal Hayatında Ermeniler, İstanbul, IQ Kültür Sanat Yayıncılık. 
Berkes, Niyazi, (1975). 100 Soruda Türkiye İktisat Tarihi 2, İstanbul, Gerçek Yayınevi, 2.bs.

Berkes, Niyazi, (2003). Türkiye'de Çağdaşlaşma, İstanbul, Yapı Kredi Yayınları.

Beşer, Ali Haydar, (2014). Ahlakta İktisat: Ahlak-i Alai'de İktisadi Meseleler, İş Ahlakı Dergisi, 7/1.

Bulut, Feryat, (2018). Toplumsal Değişim ve Siyaset Üzerinde Basının Etkisi, Haz. Merve Uğur, Türk Basın Tarihi 1, Ankara, Atatürk Araştırma Merkezi Yayınları.

Çakmak, Diren, (2011). Osmanlı İktisat Düşüncesinin Evrimi, İstanbul, Libra Yayınevi.

Çankaya, Ali, (1969). Yeni Mülkiye Tarihi ve Mülkiyeliler 1859-1968, Ankara, Mars Matbaası.

Doğaner, Yasemin, (2012). Hürriyet ve Modernleşme Estrümanı Olarak Osmanlı'da Basın, Edebiyat Fakültesi Dergisi, 29/1.

Ergin, Osman, (1977). Türkiye Maarif Tarihi 1-2, İstanbul, Eser Matbaası.

Fındıkoğlu, Fahri, (1946). Türkiye'de Iktisat Tedrisatı Tarihçesi ve Iktisat Fakültesi Teşkilatı, İstanbul, İsmail Akgün Matbaası.

Genç Hamdi-Özgür M. Erdem, (2011). Osmanlı'da Bir Politik İktisad Kitabı Tasarrufat-ı Mülkiye Serendi Arşizen, İstanbul, Kitabevi.

Gündüz, Mustafa, (2015). Osmanlı Eğitim Mirası, İstanbul, Doğu-Batı Yayınları,

Gündüz, Uğur, (2018). Osmanlı'dan Günümüze Basın ve Modernleşme, Ankara, İmge Yayınevi.

İnuğur, Nuri, (1999). Basın ve Yayın Tarihi, İstanbul, Der Yayınları.

Kadıoğlu, Zeynep Baran, (2018). Türkiye'de Medya Sahipliği Ekseninde Mülkiyet Yapılarındaki Değişimin Kronolojik Analizi (1950-2010), İnsan\&İnsan, 5/16.

Kanat, Sedat, (2018). 19. Yüzyılda Osmanlı İmparatorluğunun Eğitim Politikaları ve Toplumsal Zihniyet, Bingöl Üniversitesi Sosyal Bilimler Enstitüsü Dergisi, 8/15.

Karpat, Kemal H. (2013). İslamın Siyasallaşması, İstanbul, Timaş Yayınları.

Kaya, Mehtap, (2018). Doğuşundan Erken Cumhuriyet Dönemine Kadar Türk Basınında Gündelik Hayat İzlenimleri, Cumhuriyet Tarihi Araştırmaları Dergisi, 14/28.

Kazıcı, Ziya, (2004). Osmanlı'da Eğitim Öğretim, İstanbul, Bilge Yayıncılık.

Keçetep, Illker, (2016). Türkiye'de İktisat Biliminin Doğuşu, Uluslararası Yönetim İktisat ve İşletme Dergisi, ICAFR 16 Özel Sayısı.

Kılıç, Musa, (2012). Tanzimat Döneminde Osmanlı Hariciye Nezaretinin Ermeni Memurları, Tarih Araştırmalar Dergisi, 31/51.

Kodaman, Bayram, (1991). Abdülhamid Devri Eğitim Sistemi, Ankara, Türk Tarih Kurumu Basımevi.

Koloğlu, Orhan, (2006). Osmanlı'dan 21. Yüzyıla Basın Tarihi, İstanbul, Pozitif Yayınları.

Koloğlu, Orhan, (2010a). Osmanlı Dönemi Basının Içeriği, İstanbul, İstanbul Üniversitesi İletişim Fakültesi Yayınları. 
Koloğlu, Orhan, (2010b). Osmanlı Döneminde Basın Teknikleri ve Araçları, İstanbul, İstanbul İletişim Fakültesi Yayınları.

Kurdakul, Necdet, (1990). 19. Yüzyılda İktisat Kitapları, Tarih ve Toplum, 13/75.

Kurdakul, Necdet, (1997). Tanzimat Dönemi Basınında Sosyo-Ekonomik Fikir Hareketleri, Ankara, Kültür Bakanlığı Yayınları.

Mardin, Şerif, (2002). Siyasal ve Sosyal Bilimler, İstanbul, Illetişim Yayınları, 6.bs.

Mehmet Mithat, (11 Şubat 1869a/12 Şubat 1869b/13 Şubat 1869c/5 Şubat 1869d)/(18 Şubat 1869e/19 Şubat 1869f/20 Şubat 1869g/22 Şubat 1869i/25 Şubat 1869k/27 Şubat 1869l/1 Mart 1869m/5 Mart 1869n/6 Mart 1869o/8 Mart 1869p/11 Mart 1869r/22 Mart, 1869s/25 Mart, 1869t/31 Mart, 1869u/2 Nisan, 1869v). Ekonomi Yani İdare-i Umura Dair Yazılan Bendin Mabaadır, Terakki, $81 ; 82 ; 83 ; 84 ; 86 ; 87 ; 89 ; 90 ; 92 ; 94 ; 95 ; 98 ; 99 ; 100 ; 102 ; 108 ; 110 ; 114 ; 116,1-2 ; 3 ; 3 ; 4 ; 3 ; 3-4$; $2 ; 4 ; 2-3 ; 3 ; 4 ; 1-2 ; 2 ; 6 ; 3 ; 7 ; 3-4 ; 7 ; 7$.

Mehmet Şerif Efendi, (2 Ocak 1862a/5 Ocak 1862b/16 Ocak 1862c/21 Ocak 1862d/(26 Ocak 1862e/28 Ocak 1862f/21 Şubat 1862g/6 Mart 1862h/4 Mayıs 1862i). İlm-i Emval-i Milliye Dair Tercüme Olunmakta Bulunan Kitabın Mabaadır, Tercüman-ı Ahval, 126; 127; 132; 136; 137; 147; 153; 177, 3-4; 3-4; 2-3; 3-4; 2-3; 2-3; 3-4; 3-4; 2.

Mehmet Şerif Efendi, (3 Eylül 1861a/5 Eylül 1861b). Ekonomi Politik IIIminin Tarikiyle Hudud-ı Tabiyesinin Tahdidi Beyanındadır, Tercüman-ı Ahval, 74/75; 3;2.

Ohannes Efendi, (Temmuz 1862/Kasım 1862). İlm-i Servet-i Milel 1-2, Mecmua-i Fünun, 2;6, 86-92; 243-249.

Orman, Sabri, (1992). İlm-i Tedbir-i Menzil Oikonomia ve İktisat, Sosyo-Kültürel Değişme Sürecinde Türk Ailesi, Ankara, Başbakanlık Aile Araştırma Kurumu.

Orman, Sabri, (2001). İktisat Tarih ve Toplum, İstanbul, Küre Yayınları.

Orman, Türkan, (2018). Türkiye Modernleşme Sürecinde Etkili Olan Düşünce Akımları ve Eğitim, Edi: Eğitim Felsefesi, Ankara, Pegem Akademi.

Ortaylı, İlber, (1983). Osmanlılarda İlk Telif İktisat Elyazması, Yapıt, 46.

Ortaylı, İlber, (2000). İmparatorluğun En Uzun Yüzyılı, İstanbul, İletişim Yayınları, 6. Bs.

Ortaylı, İlber, (2011). Osmanlı Kançılaryasında Reform: Tanzimat Devri Osmanlı Diplomatikasının Bazı Yönleri, Edi: Halil İnalcık-Mehmet Seyitdanlıoğlu, Tanzimat Değişim Sürecinde Osmanlı Imparatorluğu, İstanbul, İş Bankası Kültür Yayınları.

Sayar Ahmet Güner, (2003b). Illk İktisat Muallimi Serendi Arşizen, İstanbul Üniversitesi Siyasal Bilgiler Fakültesi Dergisi, 29.

Sayar, Ahmet Güner, (2001). Osmanlı'dan 21. Yüzyıla, İstanbul, Ötüken Yayınları.

Sayar, Ahmet Güner, (2003a). Osmanlı'dan 21. Yüzyıla Ekonomik, Kültürel ve Devlet Felsefesine Ait Değişmeler, İstanbul, Ötüken Yayınları, 2.bs.

Sayar, Ahmet Güner, (2006). Osmanlı Iktisat Düşüncesinin Çağdaşlaşması, İstanbul, Ötüken Yayınları, 6.bs. 
Somel, Selçuk Akşin, (2010). Osmanlı'da Eğitim Modernleşmesi (1839-1908), İstanbul, İletişim Yayınları.

Şener, Abdullatif, (1994). Osmanlı Mali Düşüncesinin Çağdaşlaşması, Tanzimat'ın 150. Yıldönümü Uluslararası Sempozyumu 31 Ekim-3 Kasım 1989, Ankara, Türk Tarih Kurumu Basımevi.

Şinasi, (31 Temmuz 1863), Tasvir-i Efkâr, 114, 1.

Tanpınar, Ahmet Hamdi, (2001). 19. uncu Asır Türk Edebiyatı Tarihi, İstanbul, Çağlayan Yayınevi.

Tütengil, Cavit Orhan, (1965). Türkçe'de Illk İktisat Kitabı Konusu ve Yeni Bir Eser Üzerine Notlar, İktisat Fakültesi Mecmuası, 25/1-2.

Ürekli, Fatma, (2002). Tanzimat Dönemi Osmanlı Eğitim Sistemi ve Kurumları, Manas Üniversitesi Sosyal Bilimler Dergisi, 3. 